Yauba MS

Aikhionbare HA
Ogunrinde GO
Bugaje MA

\section{Significant bacteriuria in children with sickle cell anaemia in a Nigerian tertiary hospital}

DOI:http://dx.doi.org/10.4314/njp.v41i4,12

Accepted: 18th June 2014

Yauba MS $\square$ )

Aikhionbare HA, Ogunrinde GO

Bugaje MA

Department of Paediatrics,

Ahmadu Bello University Teaching

Hospital,

PMB 06, Shika-Zaria,

Kaduna state, Nigeria.

Email:saadyko@yahoo.co.uk

\begin{abstract}
Background: Urinary tract infections (UTI) in children with sickle cell anemia (SCA) may result in long term morbidity and mortality due to chronic renal dysfunction.

Objectives: To evaluate the prevalence of significant bacteriuria among children with SCA and to determine their antimicrobial sensitivity patterns of isolates.

Methods: Two hundred and seventy two children with SCA in steady state $(\mathrm{n}=185)$ and in crises $(n=87)$ aged 6 months to 15 years had their urine samples screened for significant bacteriuria. The urine samples were collected aseptically and incubated aerobically at $37^{\circ} \mathrm{C}$ for 24 hours. Children whose urine samples yielded $\geq 10^{5} \mathrm{cfu} / \mathrm{ml}$ of bacteria on two consecutive cultures were regarded as having significant bacteriuria. The antimicrobial sensitivity pattern of isolates was determined.

Results: Significant bacteriuria
\end{abstract}

was detected in $22(8.1 \%)$ of the 272 subjects, 156 boys (57.4\%) and $116(42.6 \%)$ girls. The prevalence of significant bacteriuria was higher among those in crisis, 18 (20.7\%) than among those in steady than, $4(2.2 \%)$ state: $\chi^{2}=$ $27.323, \mathrm{p}=0.001$. The most common organism isolated was Escherichia coli, 11 (50.0\%). The antibiotic with the best sensitivity was ceftriaxone. Most organisms were resistant to the commonly used antibiotics like cotrimoxazole, amoxicillin and ampicillin.

Conclusion: The prevalence of significant bacteriuria was found to be higher in SCA subjects in crisis $(20.7 \%)$ than among those in steady state $(2.2 \%)$. The most prevalent urinary pathogens were sensitive to ceftriaxone but resistant to commonly used antibiotics.

Keywords: Sickle Cell Anaemia, Children, Prevalence, Significant Bacteriuria

\section{Introduction}

Urinary tract infection (UTI) is a major cause of morbidity in children with sickle cell anemia (SCA). These children have impaired immunological state and are susceptible to recurrent infections including UTI ${ }^{1}$. Urinary tract infections in children with SCA, whether symptomatic or asymptomatic, may ultimately lead to chronic kidney disease due to repeated infarctions of the kidney, papillary necrosis, and inability of the kidneys to concentrate urine ${ }^{2}$. Significant bacteriuriais defined as the presence of $10^{5}$ or more organisms per milliliter of midstream urine ${ }^{3}$. Asymptomatic bacteriuria can also be defined as quantitative growth of bacteria $\geq 10^{5}$ colony forming units per milliliter of urine of the same organism, from aseptically collected midstream urine specimen, in the absence of symptoms of UTI, usually in repeated urine samples ${ }^{4}$. periodic study of the pattern of the organisms implicated in childhood UTI, and their antibiotic sensitivity of isolates is very important as this would contribute to reviewing treatment policies. Also, early treatment of identified cases would limit development of chronic kidney disease in this high-risk group of children. This study was undertaken to determine the prevalence of significant bacteriuriain children with SCA in a tertiary hospital. Early detection and management of ASB in SCA children may retard this progression and reduce the morbidity and mortality from CKD.

\footnotetext{
Subjects and methods

The study was conducted at the Department of Paediatrics, Ahmadu Bello University Teaching Hospital (ABUTH), Zaria, over a period of six months. The study was prospective, descriptive and cross-sectional. The sample population consisted of consecutively selected children with SCA (in steady state and in crisis) aged 6 months to 15 years. Children with SCA who had been
} 
onantibiotics one week preceding enrolment into the study, those with confirmed (or suspected) congenital urogenital anomalies and those who had recent $(<1$ week) manipulative urogenital procedure (like catheterization and cystoscopy) were excluded from the study. Those whose parents or guardians did not consent and those with $\mathrm{HbSC}$ and other forms of sickle cell disease other than SCA were also excluded. Ethical approval was obtained from the ABUTH Research Committee and a written consent obtained from guardians of subjects. Age, sex and other socio-demographic characteristics were recorded.

The urine samples were collected aseptically using standard techniques as described by Anochie et al, ${ }^{5}$ as follows: the subject's external genitalia was cleaned, midstream urine was collected, stored in a refrigerator and then submitted to the laboratory within an hour of collection. The urine samples were then incubated aerobically at $37^{\circ} \mathrm{C}$ for 24 hours within one hour of collection. Children whose urine samples yielded $\geq 10^{5} \mathrm{cfu} / \mathrm{ml}$ of bacteria on two consecutive cultures were regarded as having significant bacteriuria. Mixed growths of more than two speciesin a single urine sample were regarded as contaminants and therefore disregarded. Organisms were identified using standard identification techniques ${ }^{6}$. Antibiotic sensitivity test was also determined using standard methods ${ }^{7}$.

\section{Data analysis}

Data was analyzed using Epi Info version 3.5.3 statistical software. Values for continuous variables were expressed as frequency, mean and standard deviation. Chisquare test was used to compare subgroups. P-values less than 0.05 were considered significant.

\section{Results \\ Socio-demographic characteristics}

The ages of the 272 subjects with SCA analyzed ranged from six (6) months to 15 years with a mean age $( \pm 1$ SD) of $6.4 \pm 3.8$ years. Of these $185(68.0 \%)$ were in steady state and $87(32.0 \%)$ were in crisis (Table 1$)$. The mean age of SCA subjects in steady state was $6.8 \pm 3.9$ years while that of those in crisis was $5.6 \pm 3.7$ years $(\mathrm{p}=$ $0.00)$. There were $156(57.4 \%)$ males and $116(42.6 \%)$ females in the ratio of 1.3: 1 with no gender difference $(\mathrm{p}=0.96)$. The sex distribution in children in steady state was also not different from that of children presenting in crises $\left(\chi^{2}=0.084, p=0.39\right)$.

\begin{tabular}{|c|c|c|c|c|c|}
\hline \multirow[b]{2}{*}{$\begin{array}{l}\text { Ages } \\
\text { (Years) }\end{array}$} & \multicolumn{2}{|c|}{ In steady state, n (\%) } & \multicolumn{2}{|c|}{ In crisis, $\mathrm{n}(\%)$} & \multirow[b]{2}{*}{ Total } \\
\hline & Male & Female & Male & Female & \\
\hline$<5$ & $35(33.3)$ & $27(33.8)$ & $26(51.0)$ & $18(50.0)$ & $106(84.1)$ \\
\hline 5-9 & $40(38.1)$ & $35(43.8)$ & $16(31.4)$ & $11(30.6)$ & $102(71.5)$ \\
\hline $10-15$ & $30(28.6)$ & $18(22.5)$ & $9(17.6)$ & $7(19.4)$ & $64(44.3)$ \\
\hline Total & $\begin{array}{l}105 \\
(100.0)\end{array}$ & $80(100.0)$ & $51(100.0)$ & $36(100.0)$ & $272(100.0)$ \\
\hline
\end{tabular}

\section{Prevalence of children with significant bacteriuria}

Significant bacteriuria was detected in $22(8.1 \%)$ of the 272 subjects with SCA (Table 2). There were

$12(54.5 \%)$ males and $10(45.5 \%)$ females with significant bacteriuria $(\mathrm{p}=0.96)$. Among the 22 SCA subjects with significant bacteriuria, 13(59.1\%) were less than 5 years, 6(27.3\%) were between 5 and 9 years and

$3(13.6 \%)$ were between 10 and 15 years old. The apparent decrease in significant bacteriuria with increasing age is not significant between the age groups $(p=0.13)$. The prevalence of significant bacteriuria was higher among those in crisis, 18(20.7\%), than among those in steady state, $4(2.2 \%)-\chi^{2}=27.323, p=0.001$. Fifteen $(68.2 \%)$ of the 22 subjects with SCA with bacteriuria, were drawn from low social class, $3(13.6 \%)$ from the middle class, and 4(18.2\%) from the upper class families. Family social class was not associated with prevalence of significant bacteriuria - Fisher exact, $\mathrm{p}=0.19$.

\begin{tabular}{|c|c|c|c|c|c|}
\hline \multirow[b]{3}{*}{$\begin{array}{l}\text { Age } \\
\text { (years) }\end{array}$} & \multicolumn{2}{|c|}{ Children with SB, n (\%) } & \multicolumn{3}{|c|}{$\begin{array}{l}\text { Children without SB, } \mathrm{n} \\
(\%)\end{array}$} \\
\hline & $\begin{array}{l}\text { In steady } \\
\text { state }\end{array}$ & $\begin{array}{l}\text { In } \\
\text { crisis }\end{array}$ & In steady state & $\begin{array}{l}\text { In } \\
\text { crisis }\end{array}$ & \\
\hline & & & No & & Total \\
\hline$<5$ & $4(100.0)$ & $9(50.0)$ & $58(32.1)$ & $35(50.7)$ & $106(39.0)$ \\
\hline $5-9$ & $0(0.0)$ & $6(33.3)$ & $75(41.4)$ & $21(30.5)$ & $102(37.5)$ \\
\hline $10-15$ & $0(0.0)$ & $3(16.7)$ & $48(26.5)$ & $13(18.8)$ & $64(23.5)$ \\
\hline Total & $4(100.0)$ & $18(100.0)$ & $181(100.0)$ & $69(100.0)$ & $272(100.0)$ \\
\hline
\end{tabular}

$X^{2}=4.150, d f=2, p=0.13$

\section{Bacterial isolates}

A total of 22 organisms were isolated from the 22 children with SCA (Table 3). The most frequently isolated organism was Escherichia coli $(11 ; 50.0 \%)$ followed by Klebsiellapneumonia (5; 22.7\%) and Proteus species (3; 13.6. The least common isolates were Staphylococcus aureus $(2 ; 9.1 \%)$ and Salmonella typhi $(1 ; 4.6 \%)$ Table 3. Antimicrobial sensitivity test revealed that Escherichia coli, Klebsiella pneumoniaand Proteus species were sensitive to gentamycin (95.5\%), ciprofloxacin (100\%) and ceftriaxone $(100 \%)$.The organisms were also sensitive to nitrofurantoin $(68.2 \%)$, cephalexine $(61.9 \%)$, nalidixic acid $(54.5 \%)$ and clavulonic acid potentiated amoxycillin $(45.5 \%)$. The isolates were least sensitive to ampicillin (9.1\%), cotrimoxazole (13.6\%) and amoxicil$\operatorname{lin}(18.2 \%)$.

\begin{tabular}{ll}
\hline \multicolumn{2}{c}{ Table 3: Urinary bacterial isolates among patients with SCA } \\
Organisms & Frequency $(\%)$ \\
\hline Escherichiacoli & $11(50.0)$ \\
Klebsiellaspecies & $5(22.7)$ \\
Proteus species & $3(13.6)$ \\
Staphylococcusaureus & $2(9.1)$ \\
Salmonella typhi & $1(4.6)$ \\
Total & $22(100.0)$ \\
\hline
\end{tabular}




\section{Discussion}

The overall prevalence of significant bacteriuria in children with SCA in this study was found to be $8.1 \%$. Higher prevalence of significant bacteriuria of $26.7 \%$ was reported amongst HbSS patients in $\mathrm{Zaria}^{8}, 26.0 \%$ in Maiduguri ${ }^{9}$ all in Nigeria and $10.9 \%$ in Jamaica ${ }^{10}$. The prevalence observed in this study was also lower than $12.85 \%$ reported by Akinbami et $a l^{11}$ in Lagos and $21.6 \%$ reported by Asinobi et $a l^{12}$ in Ibadan. The lower prevalence of significant bacteriuria obtained in our study could be due to the fact that most of our study population were SCA subjects in steady state, while Zaria $^{8}$, Maiduguri ${ }^{9}$ and Ibadan ${ }^{12}$ studies were febrile children with SCA. Differences in the methodology may have contributed to the lower prevalence observed in our study as compared to studies by Akinbami et $a l^{11}$ and Cumming et al. ${ }^{10}$ Whilst our study used clean-catch, mid -stream and supra pubic aspiration urine specimen, Cumming and Akinbami et al ${ }^{11}$ used only clean catch, midstream urine sample for their study. Supra pubic aspiration is more aseptic technique with reduced contamination rate.

However, the prevalence observed in this study was higher than the $6.0 \%$ reported by Chuckwu et $a l^{13}$ in Enugu. The higher prevalence observed in our study as compared to that reported by Chuckwu et $a l^{13}$ may be contributed by those children with SCA crisis. This study included children with SCA both in crisis and in steady state while Chuckwu et $a l^{13}$ included only children in steady state.

This study revealed that prevalence of significant bacteriuria did not decreased with increasing age a finding different from that reported by $\mathrm{Akuse}^{8}$ and Mava et $a l^{9}$ where their prevalence decreases with increasing age. The differences in the genetic constitutions among the study populations may explain the difference in the prevalence. Regarding those in crisis, significant bacteriuria was also found to be commoner among the age group less than 5 years than in the older children, a finding similar to that of Akuse $^{7}$ and Mava et al ${ }^{9}$. Preponderance of significant bacteriuria in this age group could be explained by the fact of incompletely developed immunity $^{8,9}$.

Our study revealed that significant bacteriuria was not associated with gender even though it had been shown that bactriuria is commoner in females than males in children older than one year ${ }^{9,12,14}$. This could be attributed to the small number of children with confirmed significant bacteriuria in the present study and the varying cultural/ religious practices in these environments. In the environment where the current study was conducted male children are not often circumcised before the age of seven years. Early circumcision is the norm in Southern parts of Nigeria and the Western world where Akinola et $a l^{14}$ conducted their study. Lack of circumcision has been associated with increased risk of UTI in boys ${ }^{15}$. Significant bacteriuria being not associated with child's socio-economic status contrasted with the finding by Chukwu et $a l^{13}$.
The current study also showed that the percentage of patients with significant bacteriuria was significantly higher in children with SCA crisis than in those in steady state. The $20.7 \%$ prevalence of significant bacteriuria in children with sickle cell crises obtained in this study is in agreement with the $21.6 \%$ prevalence reported earlier by Asinobi et $a l^{12}$. On the other hand, the $20.7 \%$ prevalence of significant bacteriuria observed in this study in those with SCA crisis was higher than that $(10.0 \%)$ observed by Tarry et $a l^{16}$ in USA and $25.6 \%$ reported by Elbashier and $\mathrm{Badu}^{17}$ in Saudi Arabia. Differences in the study design and age distribution of study population used might have contributed to the difference in the prevalence. The study by Tarry et $a l^{16}$ was retrospective and included children above 15 years of age while this study included children less than 15 years. This study included only children with SCA while Elbashier and $\mathrm{Badu}^{17}$ included other haemoglobin phenotypes and their study was retrospective in design, which may explain the difference observed in their study as compared to the present study. Racial variations may also contribute to the differences in the prevalence.

The $2.2 \%$ prevalence of significant bacteriuria in steady state SCA subjects obtained in our study was lower than the $6.0 \%$ prevalence obtained by Chukwu et $a l^{13}$ in Enugu and the $5.8 \%$ reported by Ajasin and Adegbola ${ }^{15}$ in Lagos in children with SCA in steady state. The lower prevalence observed in this study as compared to those of Chukwu et $a l^{13}$ and Ajasin and Adegbola ${ }^{18}$ may be due to the difference in methods of urine collection. Whilst this study used clean-catch, mid-stream and supra pubic aspiration specimen, Chukwu et $a l^{13}$ and Ajasin and Adegbola ${ }^{18}$ used only clean catch, midstream urine sample for their study.

The most frequently isolated organism from the urine specimens was Escherichia coli, followed by Klebsiellaspp, a finding similar to that of other studies ${ }^{9,14}$. The virulent factors associated with E.coli ${ }^{18}$ may have contributed to the organisms being the most frequently isolated. Salmonella typhi and Staphylococcus aureus were the organisms least isolated in our study, a findingsimilar to that reported byothers 9 . The rarity of Salmonella UTI in our study as well as these other studies was because Salmonella typhi is not a common cause of UTI in children.

This study revealed that most of the pathogens isolated were resistant to cotrimoxazole, ampicillin, cephalexin and amoxicillin but highly sensitive to ceftriaxone, ciprofloxacin, gentamycin, cefuroxime and nitrofurantoin. These findings were similar to those reported by other workers $^{12,19}$. This may be partly attributed to the high cost of these drugs.

\section{Conclusion}

The prevalence of significant bacteriuria was found to be higher in SCA subjects in crisis than in those in 
steady state. Escherichia coli still remained the commonest pathogen isolated. There was a high degree of resistance of isolated urinary organisms to commonly used antibiotics. It is recommended that routine urine screening for UTI be carried out in children, particularly under-fives, presenting to our hospitals with SCA crisis. Ceftriaxone, cefuroxime or gentamycin should be a drug of choice for empiric treatment of UTI in children with SCA.

\section{Authors' contributions}

MS conceived the study, participated in the design and coordination of the study, collected the samples, contributed in the laboratory work, analyzed the data and wrote the final manuscript. HA, GO and MA participated in the design, writing, analyzing and supervision of the study. All contributors approved the final version of the manuscript.

Conflict of interest: None

Funding: None

\section{Acknowledgements}

We wish to acknowledge Dr. Adamu Ali Zainab of the General Out-patient Department, ABUTH, Dr. Suleiman Saidu Bashir of the Department of Community Medicine, ABUTH for their immense technical assistance as well as Dr. Ibrahim Adulrasul of the Department of Microbiology, ABUTH for assisting in the laboratory aspect of this study.

\section{References}

1. Kizito ME, Mworozi E, Ndugwa C, Serjeant GR. Bacteraemia in homozygous sickle cell disease in Africa: Is pneumococcal prophylaxis justified? Arch Dis Child. 2007; 92:21-23

2. Chukwu BF, Okafor HU, Ikefuna AN. Socio-demographic factors associated with asymptomatic bacteriuria in children with sickle cell anemia in a tertiary health facility in South eastern, Nigeria. Italian J Pediatr. 2011; 3: 1-5.

3. Okafor HU, Okoro BA, Ibe BC, Njoku-Obi NU. Prevalence of asymptomatic bacteriuria among nursery school children. Nig $J$ Paediatr 1993; 20: 84-88.

4. Eke F, Eke NN. Urinary tract infection. In: Azubuike JC, Nkangineme KEO, editors. Paediatrics and Child Health in a Tropical Region. 1st ed. Owerri: African Education Service; 1999. pp. 326-8.

5. Anochie IC, Nkanginieme KEO, Eke FU. The influence of instruction about the methods of urine collection and storage on prevalence of urinary tract infection. Niger J Paediatr 2002; 28: 39-42.

6. Nester EW, Robert EC, Pearsall NN, Anderson DG, Nester MT. Dynamics of Bacterial Growth. In: Microbiology and Human Perspective. MacGraw-Hall: Boston, 1998: 85-106.

7. Cheesbrough M. District laboratory practice in tropical countries. In: Cheesbrough M (ed). Cambridge University Press, United Kingdom, 2000: 124-145.
8. Akuse RM. The Pattern of Bacterial Infection and Intercurrent Morbidity in Sickle Cell Disease Patients. A Dissertation Submitted to the National Postgraduate Medical College of Nigeria in Part Fulfillment of the Requirements for the Fellowship of the College 1990: 318-323.

9. Mava Y, Ambe JP, Bello M, Watila I, Pius S. Evaluation of the nitrite test in screening for urinary tract infection in febrile children with sickle Cell anaemia in Maiduguri- Nigeria. Niger Med J 2011; 52: 45-48.

10. Cumming V, Ali S, Forrester T, Roye-Green K, Reid M. Asymptomatic bacteriuria in sickle cell disease: A cross-sectional study. BMC Infect Dis 2006;6:46.

11. Akinbami AA, Ajibola S, Bode-Shojobi I, Oshinaike O, Adediran A, Ojelabi O et al. Prevalence of significant bacteriuria among symptomatic and asymptomatic homozygous sickle cell disease patients in a tertiary hospital in Lagos, Nigeria. Niger J Clin Pract 2014; 17: 163 - 167. http:// www.njcponline.com

12. Asinobi AO, Fatunde OJ, Brown BJ, Osinusi K, Fasina NA. Urinary tract infection in febrile children with sickle cell anaemia in Ibadan, Nigeria. Ann Trop. Paediatr 2003; 23: 129-134.
13. Chukwu BF, Okafor HU, Ikefuna AN. Asymptomatic bacteriuria and sensitivity pattern in children with sickle cell anaemia in a tertiary health centre in Enugu, South East Nigeria. Ital J Pediatr. 2011; 37: 45.

14. Akinola NO, Stevens SME, Franklin IM, Nash GB, Stuart J. Subclinical ischaemic episodes during the steady state of sickle cell anaemia. J Clin Pathol 1992; 45: $902-$ 6.

15. Herzog L. Urinary tract infections and circumcision. Am J Dis Child 1989; 143: 349-350.

16. Tarry WF, Dukket JW, McSynder. Urological complicationsof sickle cell disease in a paediatric population. J Urol 1987; 138: 592-594.

17. Elbashier AM, Badu GA. Pattern of bacteriuria in patients with sickle cell disease in Qatif Central Hospital. Saudi Med J 1991; 12: 121-124.

18. Ajasin MA, Adegbola RA. Asymptomatic bacteriuria in children with sickle cell anaemia. Niger $J$ Paediatr 1988; 15: 19-25.

19. Owa JA. Urinary Tract Infections in Children. In: Azubuike JC, Nkanginieme KEO (editors) Paediatrics and Child health in a Tropical Region. Second ed. Owerri, African Educational Service: 2007: 480-487. 